The making of a European healthcare union

\title{
a federalist perspective
}

Vollaard, Hans; van de Bovenkamp, Hester M.; Martinsen, Dorte Sindbjerg

Published in:

Journal of European Public Policy

DOI:

$10.1080 / 13501763.2015 .1034160$

Publication date:

2016

Document version

Early version, also known as pre-print

Citation for published version (APA):

Vollaard, H., van de Bovenkamp, H. M., \& Martinsen, D. S. (2016). The making of a European healthcare union: a federalist perspective. Journal of European Public Policy, 23(2), 157-176. [1].

https://doi.org/10.1080/13501763.2015.1034160 


\title{
The making of a European healthcare union: a federalist perspective
}

\author{
Hans Vollaard, Hester van de Bovenkamp and Dorte Sindbjerg Martinsen \\ Published in \\ Journal of European Public Policy
}

\begin{abstract}
EU involvement in healthcare policies is growing, despite the fact that national governments prefer to keep an almost exclusive say in these policies. This article explains how this shift of authority could happen and explores whether it will lead to a European healthcare union. It argues that federalism offers the most fruitful way to do so because of its sensitivity to the EU's institutional settings and to the territorial dimension of politics. The division of competences and national diversity of healthcare systems have been major obstacles for the formation of a healthcare union. However, the EU obtained a role in healthcare through the impact of nonhealthcare legislation, voluntary co-operation, court rulings, governments' joint-decision traps, and fiscal stress of member states. The emerging European healthcare union is a system of cooperative federalism without much cost-sharing. The healthcare union's robustness is limited, also because it does not generate much loyalty towards the EU.
\end{abstract}

KEYWORDS: (European integration; federalism; healthcare; joint-decision trap; patients' rights directive) 


\section{INTRODUCTION}

In 1952, the French minister of health, Paul Ribeyre, proposed establishing a European Health Community similar to the European Coal and Steel Community (Parsons 2003: 86ff). He specified in a draft treaty of 330 articles how supranational institutions should regulate health policies. Ribeyre's proposal failed to receive support from European governments, including his own, and from powerful interest groups. For many years, health policies remained an exclusive national competence in Europe, and to this day, national governments within the European Union (EU) prefer to keep an almost exclusive say in healthcare policies, which entails organising, financing, and providing diagnoses, cares and cures to people who are ill. A sizeable majority of EU citizens also prefer national decision-making on healthcare over joint decisionmaking by national governments and the EU (European Commission 2010). This view is reflected in Article 168 of the Treaty on the Functioning of the European Union: "[t]he Union should respect the responsibilities of the Member States for the definition of their health policy and for the organization and delivery of health services and medical care". Nevertheless, EU involvement in health policies has expanded, in terms of both scope and depth. With the Maastricht Treaty (in force since 1993), the supranational European Union (EU) obtained a say in public health, which includes all policy measures to increase the physical and mental wellbeing of all people (such as anti-pollution policies). Today, the scope of EU health policies includes access to healthcare and the quality and safety of healthcare goods and services. The EU thus influences even the core of member states' healthcare policies: the delivery of services 
to patients. Moreover, the depth of EU involvement ranges from sharing information and voluntary standardisation of norms to enforcing EU laws (Vollaard et al. 2013).

The growing EU involvement in healthcare policies leads to the two key questions of this article. First, how could this shift of authority to the EU level happen despite the reluctance, if not opposition, from national governments and their citizens? Second, where will this shift lead to, a European healthcare union similar to the Area of Justice, Freedom and Security or the European Higher Education Area? The rise of a "new compound European healthcare state" has already been observed (Lamping 2005: 43), but it has remained unclear what shape it will take. We argue that federalism offers the most fruitful way to explain the trajectory and nature of EU involvement in healthcare policies because of its sensitivity to the specific institutional settings of multilevel polities and to the territorial dimension of politics. Comparative studies of federalism have shown the causal mechanisms behind the territorial allocation of authority on welfare policies in multilevel systems such as those of Australia, Canada, Switzerland and the EU (Obinger et al. 2005a, 2005b). These mechanisms indicate how member states' objections against EU involvement in welfare policies can be circumvented while the territorial interests of the member states continue to leave their mark on welfare policies. After introducing federalism in more detail, this article uses this perspective to show how EU involvement in healthcare policies has been unlikely but has taken place nonetheless. The article subsequently defines the nature of the European healthcare union in the making and reflects upon its political sustainability with the help of the various federalist arrangements that are distinguished in multilevel polities. 
The added value of this article is not only to analyse EU involvement in healthcare from a single political science perspective (see, for a holistic analysis from a legal perspective, Hervey and McHale [2015] and, for overviews of EU health policies including healthcare, Greer [2009] and Mossialos et al. [2010]) but also to empirically demonstrate the utility of federalism for explaining task allocation in the EU (Benson and Jordan 2008).

\section{THE EXPLANATORY VALUE OF FEDERALISM}

\section{Defining a European healthcare union}

Before discussing the explanatory value of federalism, it should be clear what a European healthcare union is. The first two words of this concept are relatively easy to define: European refers here to the European Union and its predecessors, and healthcare concerns the organisation, financing, and provision of diagnosis, care, and cure to ill people. This definition also includes the means of diagnosis, care, and cure, such as pharmaceuticals. Defining union is more difficult because the term rather vaguely refers to a commonality that makes a certain collection of units a distinct entity, and this commonality may be of varying nature. With respect to a healthcare union, it could refer to the common use by professionals, patients or other actors of the units' healthcare systems, the common values and standards that guide these healthcare systems, the union's common institutions for healthcare policy-making, or a common regulation or financing of (parts of) the healthcare systems. A healthcare union could thus vary not only in nature but also in strength from less to more and weaker to stronger commonalities. 


\section{Problematic explanations of European healthcare integration}

Analyses of the evolution of EU involvement in public health and healthcare policies have often highlighted its patchy nature, which resulted from the combination of the impact of European market legislation, responses to health crises and threats, such as cancer, AIDS and BSE, and the diffusion of information and standards through European health policy networks (Hervey and Vanhercke [2010]; Lamping and Steffen [2009]). The European Commission and the Court of Justice of the European Union (CJEU) are often cited as the most influential actors through their provision of the infrastructure for European health policy networks and application of EU market legislation to health policies, respectively. In this article, we move beyond these policyspecific explanations, which allows us to become better aware of and explain the peculiar dynamics of EU involvement in healthcare.

Intergovernmentalism, one of the classical general theories of European integration, considers the preferences of national governments, in particular the most powerful member states, as decisive for EU involvement in any policy area. However, this is a problematic explanation for the emergence of a healthcare union because of the consistent and widespread opposition to EU involvement in healthcare among national governments. Additionally, the CJEU, the Commission and other non-state actors have also pushed EU involvement forward beyond national preferences concerning healthcare.

According to neo-functionalism, another classical perspective on integration, functional interdependencies exert integrative pressures from one policy area or issue to another. Non- 
state actors, such as interest groups and European institutions, are perceived to be instrumental in this spill-over process. Indeed, studies show the importance of legislation on issues related to healthcare and the supranational entrepreneurship of the European Commission, judicial policy-making by the CJEU and European networks of experts and activists as driving forces of European integration of health policies (Lamping [2005]; Martinsen [2005]; Trubek et al. [2009]). Neo-functionalism thus indicates potential actors and sources that could circumvent governments' aversion towards healthcare integration (Greer 2006). However, the neo-functionalist expectation that actors who benefit from European integration would shift their loyalties towards the new European decision-making centre has been empirically refuted (Risse 2005). Additionally, it remains unclear under what conditions functional interdependencies would lead to integration. For example, the case of the UK shows that disintegration, also with respect to healthcare, can occur despite dense and tight functional connections among its regions. Additionally, strong economic interdependencies and an abundance of market-making integration have not resulted in a full-fledged market-correcting, nationwide welfare regime in the USA (Streeck 1995). Thus, despite functional interdependencies, the EU market should not be expected to quasi-automatically increase EU involvement in healthcare, and as such, neo-functionalism is also a problematic explanation of an emerging European healthcare union.

\section{Fruitful federalism}


After a period of relative oblivion, the classical perspective of federalism has been increasingly used to empirically analyse the EU (Benson and Jordan, 2008). As a political structure, federalism is essentially about a combination of self-rule and shared rule (Elazar 1987). Whereas only few expect the EU to develop into a federal state, it has sufficient in common with multilevel systems such as the USA, Germany and Canada to explain task allocation with the help of federalism. The commonalities concern the division of rule between the central and the sub-units' levels of governance, the autonomy of each level of governance in at least some tasks in their respective territories, formal arrangements to change the division of rule, and the representation of the sub-units at the central level (Börzel and Hosli [2003: 186-187]; Kelemen [2003: 185]; Obinger et al. [2005a: 9]). These commonalities thus relate to both the institutional set-up of a political system and the territorial dimension of politics. From the perspective of federalism, the governments of member states are not assumed to be the only decisive actors (as in intergovernmentalism) or to be reactive to the activities of non-state actors (as in neofunctionalism). Instead, federalism can encompass an active role of both governments and nonstate actors in its explanation of European integration (Benson and Jordan 2011).Furthermore, federalism underlines the significance of the exact decision-making procedure, and it sheds light on how the interplay between functional and territorial politics leaves its mark on policy developments. Federalism as a theory of task allocation thus offers a more comprehensive understanding of the trajectory of policy integration than the theories discussed above.

An additional advantage of federalism is that it provides analytical tools for describing the nature of a healthcare union. In the scholarly literature, three types of federalism have been discerned: dual (strict division of rule between the levels of governance), joint-decision or 
cooperative (shared rule between the levels), and shared-cost (funding from one to another level) (Banting [2005]; Börzel and Hosli [2003]). Whereas dual federalism emphasises the institutional autonomy of the two levels of governance, cooperative federalism concerns a system under which policy competences are shared. In shared-cost federalism, the central level provides sub-units with financial means if both levels agree on the conditions. Each model of federalism has its particular balance of representing territorial (sub-unit) and functional (central) interests (Börzel and Hosli [2003: 184]; Egeberg [2001]). The USA most closely resembled dual federalism once, but it shifted towards shared-cost federalism, and Germany combines cooperative with shared-cost federalism. In general, the EU has been characterised as an instance of cooperative federalism (Benson and Jordan 2011). With only a limited budget to share with the member states, it relies largely on regulation as the means of rule. In a system of cooperative federalism, integration and policy outcomes are the result of neither central, supranational actors nor national, sub-unit actors exclusively. Yes, the CJEU can adjudicate in important issues, the European Commission has the right to propose legislation and to enforce its implementation, and the political groups in the European Parliament co-decide on EU legislation. However, the member states' governments still represent territorial interests at the central level through their participation in the Council of Ministers. The latter's legislative centrality implies a certain asymmetry in political representation whereby territorial interests still tend to dominate over functional ones (Börzel and Hosli [2003: 190]). Additionally, national courts mediate the application of CJEU rulings. Additionally, national courts mediate the application of CJEU rulings. EU policy outcomes are thus conditioned by the institutional structures through which territorial interests are continuously voiced. In particular, where EU 
decision-making depends on the (nearly) unanimous agreement of the member states, socalled joint-decision traps hinder optimal solutions to policy problems (Scharpf 1988, 2011). When one or some of the member states can easily veto a decision, decision-making results in the lowest common denominator or the status quo.

Federalist explanations of task allocation in the process of European integration still need further theoretical refinement and empirical testing (Benson and Jordan 2011). Given the commonalities among federative systems, the method of comparative federalism allows us to distinguish the causal mechanisms behind the reallocation of (welfare) policies. A number of comparative studies indicate that federalist arrangements inhibit the emergence of welfare schemes (see Obinger et al. 2005a). Free mobility and a lack of federal transfers in a multilevel polity could prevent individual member states from establishing welfare schemes that would otherwise be overburdened by needy citizens from elsewhere. If member states do establish welfare schemes, mutual diversity hampers their integration into a larger scheme. Misfits in terms of organisation and policy ideas between the proposed and existing welfare schemes, diverging preferences, vested interests and members' veto powers are likely to be insurmountable obstacles in this respect. However, as Obinger et al. (2005a, 2005b) observe, the inhibitive impact of federalism on the development of welfare schemes is contingent upon a series of conditions. Federal authorities can also have the institutional rights or budgetary means to expand their roles in welfare policies, constitutional courts could be willing to accept an expansive central say in welfare policies, and political parties and interest groups might push for an expansive central role in welfare policies. The exact institutional arrangements and the representation of functional and territorial interests determine whether and how the federal 
centre could obtain tasks in welfare policies. From comparative federalist studies, causal mechanisms can thus be derived to explain whether and how authority on welfare policies is reallocated from lower to higher levels of governance. The following sections discuss why the emergence of an EU healthcare union could occur, even though it has been rather unlikely.

\section{THE UNLIKELIHOOD OF A EUROPEAN HEALTHCARE UNION}

\section{No central jurisdiction and national policy pre-emption}

Studies of comparative federalism and welfare state development indicate manifold factors that would make EU involvement in healthcare policies rather unlikely. A simple but crucial factor is the division of rule. After the failure of the quickly forgotten proposal by Ribeyre, healthcare did not feature in the Treaties of Rome (in force in 1958). The treaty on the European Economic Community (EEC) focused on the internal market and external trade, leaving social protection to the member states. Without any explicit jurisdiction, the central level was not expected to interfere in the healthcare systems within the member states (Martinsen and Falkner 2011). The introduction of a European framework for authorising pharmaceuticals in 1965 in the aftermath of the thalidomide tragedy was the proverbial exception in this respect. The fairly strict division of rule, an instance of dual federalism, enabled member states to develop their healthcare systems without much European involvement (cf. Obinger et al. [2005a: 45]; Obinger et al. [2005b: 550]). Through this preemptive occupation of the healthcare policy area by the national governments, the relatively young nationwide healthcare systems could become firmly entrenched within the member 
states. Only when national governments felt that the EU's centre might interfere too much in healthcare policies because of an expanding EU role in public health did they explicitly set down their healthcare prerogatives in European primary law through the Amsterdam Treaty (in force in 1999). Governments' desire to maintain national sovereignty in organising and financing their healthcare systems has lived on, as illustrated by a collective statement from the German, Portuguese and Slovenian governments: "[w]e are determined to maintain the national competencies for healthcare organization" (Notes of the Trio Presidency 2007). The preemption of the healthcare policy area by national governments and their continuing adherence to the principle of subsidiarity with respect to healthcare have thus limited the possibilities to put healthcare firmly on the European policy agenda (Princen 2009: Ch.6).

\section{National diversity and the joint-decision trap with a default option}

After WWII, a wide variety of healthcare systems emerged within the member states. A distinction is often made between tax-financed, universal, state-led national health service systems and social insurance systems financed by premium contributions, with various arrangements depending on occupation, region, ideology or religion and run foremost by private health providers and health insurance funds (often in close cooperation with social partners) within a public law framework. This distinction is based on the founding period of healthcare systems (until the 1970s). Most social insurance systems now also have universal coverage, and many national health service systems have given more space for private healthcare providers. However, diversity still abounds because of the introduction of new 
governance arrangements, such as competition and patient choice in a number of systems, and the various EU enlargement rounds that expanded the variety of systems.

As the history of federalism and welfare state development shows, diverse, entrenched systems are difficult to integrate into a larger union because of the ensuing vested interests, organisational differences and diversity of preferences as well as territorially fragmented interest groups (Obinger et al. 2005a, 2005b). If the EU had been an authoritarian system, as multilevel Germany was in its early days, these obstacles to unification could have been overcome (Obinger et al. 2005b), and this also holds if the EU could have obtained (exclusive) jurisdiction on healthcare. However, treaties that would enshrine EU competence in healthcare have to be negotiated by the member states' governments and ratified by their domestic constituencies, and this is rather unlikely to happen given these governments' resistance to EU interference in healthcare. Even where the EU could adopt secondary European laws (regulations and directives) related to health(care) policies, doing so often required the approval of (nearly) all national governments in the Council of the EU until the adoption of the Lisbon Treaty (in force since 2009), at least on non-market issues. Approval is also rather difficult given the diversity of the healthcare systems involved. Typical for systems of cooperative federalism, the EU thus faces a joint-decision trap whereby (near) unanimity is required to make decisions (Scharpf 1988). The EU also relies heavily on the member states to implement EU primary, secondary and case law. The incentive to adopt or implement EU law is rather limited given that the default option of not deciding-which results in less European interference in their healthcare systems-is closer to member states' preferences. The 
combination of diversity and a joint-decision trap constitutes a significant obstacle for forming a European healthcare union.

\section{The EU centre lacks many other means to expand its involvement}

EU interference in healthcare has not only been constrained by its limited jurisdiction and the veto power of the collective of member states. It also lacks means that other centres in federal systems have used to expand their role in welfare policies. For example, supranational involvement in healthcare could be increased through financial support. Canada provides an informative example in this regard; its federal government has enhanced its role in healthcare by providing grants to the provinces in exchange for a larger say in their healthcare policies (Banting 1995, 2005). Lacking an autonomous tax base and a sizeable budget, EU authorities are constrained in expanding their influence in this way (Obinger et al. 2005b: 565). Shared-cost federalism in healthcare policies in the EU thus remains an unlikely future.

Powerful interest groups and political parties can be another driving force behind expanding the centre's role in welfare policies. For example, Christian democratic and social democratic parties pushed for central welfare arrangements despite territorial divisions in Austria and Germany. However, EU authorities cannot rely on political parties and interest groups that are sufficiently powerful and willing to overcome the diversity of healthcare arrangements across the EU. A call for unifying European healthcare policies is barely heard. Most political parties honour the preferences of their citizens to keep healthcare by and large a national competence (Martinsen and Falkner 2011). Since the CJEU provided patients with more opportunities to obtain cross-border healthcare, "there is essentially no evidence of 
economic, political, or social supporting coalitions" to facilitate the ensuing implementation (Greer 2011: 191). Interest group support for patient mobility legislation remains limited (Greer and Rauscher 2011: 235). The limited societal support may not come as a surprise given that the interests of patient movements, health provider associations, and health insurers are foremost vested in national healthcare systems.

Comparative studies have shown that resistance can also be overcome by shifting to an arena that comprises actors who are more willing to support central welfare policies. For example, Austria and Germany have relied on the para-fiscal and para-statal execution of the centre's social security by employer federations and trade unions (Obinger et al. 2005b: 565). Again, this is scarcely an option for healthcare in the EU. The European Commission facilitates a variety of platforms for stakeholders to discuss health matters at the EU level and to set up a framework for creating cross-border reference networks for highly specialised healthcare, but the direct execution of European healthcare policies by third parties, such as health providers, remains difficult if not impossible because of the member states' competences and involvement in organising and financing healthcare.

\section{ESCAPE ROUTES TOWARDS A EUROPEAN HEALTHCARE UNION}


Making a European healthcare union in the multilevel EU appears to face insurmountable hurdles. Nevertheless, comparisons with the making of welfare regimes in other multilevel entities show the possible escape routes towards some sort of European healthcare union.

\section{European legislation's indirect impact on healthcare}

In Switzerland, federal authorities could begin to strengthen their say in social policies by regulatory, non-redistributive legislation on related issues. Similarly, without many financial and administrative sources, EU authorities have few other powerful means for expanding their influence in healthcare policies except for legislation on which the European Commission holds the right of initiative (Obinger et al. 2005b: 565-566). Because policy areas are difficult to keep completely separated, the European Commission thus has a means to expand its say in healthcare indirectly. Given the focus of the 1958 EEC Treaty, European legislation that is

relevant to healthcare foremost relates to the free movement of goods, services, workers and capital (Hervey and Vanhercke 2010). Since 1958, European regulations have coordinated the access to public healthcare systems for employees who work elsewhere in the EEC/EU. By now, these so-called coordination regulations include everyone in public healthcare (insurance) systems, covering almost all legal residents of the EU. An accompanying European Health Insurance Card was launched to facilitate obtaining emergency care abroad (Vollaard 2006), and to facilitate the free movement of workers, European legislation on the mutual recognition of diplomas set minimum standards regarding the education and training of health professionals who seek registration elsewhere in the EU. Moreover, the Internal Market 
Information System (IMI) assists member states in exchanging information about health professionals' right to practice.

The free movement of goods has entailed legislation to guarantee the safety and quality of pharmaceuticals, blood, human tissue, human organs and medical devices in the internal market as well as to make transparent national pricing and reimbursement rules of medicines (Lamping and Steffen 2009). The creation of a level playing field in the internal market also brought about standards on health and safety at work, including working time. Legislation on the free movement of services has yet to face exemptions for (private) health insurances that are part of any social security system, but it does show how market legislation is increasingly limiting the options for national governments to organise, finance and provide healthcare (Thomson and Mossialos 2010). Rather than the EU respecting national competences on healthcare, national governments should respect EU legislation on fair competition (without trade-disturbing state subsidies to health providers or health insurers) and access to healthcare markets without hindering free movement or discriminating under the conditions laid out by EU authorities.

Previously, unanimous decision-making also allowed individual governments to block market legislation for its undesired impact on their healthcare systems. However, unanimous voting on market legislation has been gradually replaced by qualified-majority voting to avoid the joint-decision trap, in particular with respect to market issues. As a result, individual governments have less opportunity to prevent market legislation with (unintended or unwanted) impact on healthcare, which contributes to the growing EU involvement in 
healthcare. European integration also involves a policy area that is closely interlinked with healthcare. Building upon a number of voluntary initiatives to fight 'new' diseases, such as AIDS and cancer, the EU obtained a legal basis for a complementary role regarding public health in the 1990s (McKee et al. 2010). It includes the guarantee of high-level health protection in all policies and activities and support for member states to coordinate their disease prevention, food safety and health promotion efforts (including tobacco control and the fight against drugs abuse). Gradually, healthcare has also become part of the mutual exchange of information and EU-funded research in efforts, for instance, to learn about the financial and health performance of healthcare systems in the face of demographic and technological developments (Hervey and Vanhercke 2010). Nevertheless, the relative lack of expertise and legislative powers, as well as financial and administrative capacities, constrains the European Commission from including health considerations in all European policies, and questions remain regarding the extent to which findings from EU-funded research are used in national policies (McKee et al. 2010).

\section{Court rulings with national governments caught in a joint-decision trap}

In multilevel systems such as Australia's, court rulings have been a major impetus for social policy initiatives (Obinger et al. 2005: 566). This also holds for the EU with respect to healthcare, partly because of the EU's decision-making procedures. The European market challenges the territorially closed national healthcare systems, which were initially sheltered from cross-border competition and the free movement of goods, services, persons and capital. Although cross-border health consumption and provision are still limited (Glinos et al. 2012), 
litigation has entailed a considerable contribution of CJEU case law in health matters. European legislation resulting from compromises between governments, the European Commission and, more recently, the European Parliament is often somewhat ambiguous. The laws provide leeway in the CJEU's interpretation, which the court has used in cases concerning healthcare (Martinsen and Falkner 2011: 132). However, member states can change European legislation to roll back undesired interpretations by the CJEU. For example, when the CJEU stated in the late 1970s that a patient could seek any effective healthcare treatment abroad if it would not be available in his or her home country, the ten member states decided to indicate more clearly that only treatments that are part of a patient's healthcare package can be subject to reimbursement for cross-border healthcare under the Coordination Regulations (Martinsen 2005: 1038). This exemplifies the importance of territorial politics, where the territorial interests represented by member states in the Council result in legislative corrections to court decisions regarding maintaining the principle of state territoriality in healthcare.

However, the diversity among a growing number of member states makes it increasingly difficult to roll back undesired CJEU case law. The joint-decision trap in healthcare policies thus functions as an obstacle not only to EU involvement in healthcare but also to revoking case law concerning healthcare. A major example is the process after the outcry of all national governments against applying market legislation to healthcare services in a series of court cases that began in 1998 and that allowed reimbursement for cross-border healthcare services and goods without prior authorisation, albeit under certain conditions. Governments called for excluding healthcare from the interference of the EU, or at least its market legislation, to restore the principle of state territoriality but could not fully counter the case law because of 
disagreements about the desired procedure (Martinsen and Falkner 2011: 134). Because the Court based its verdicts directly on the free movement principles laid down in the treaties, they could only be rolled back by changing these fundamental treaty parts, which proved impossible. Additionally, some governments initially refused to discuss healthcare at the EU level at all but eventually accepted that-albeit foremost informally-health politicians should shape EU involvement in healthcare rather than courts (Hervey and Vanhercke 2010).

The failure of national governments to collectively counter the CJEU case law offered the European Commission the opportunity to keep the issue of cross-border healthcare on the agenda, and it did so by launching studies and discussion platforms, scrutinising member states' compliance with case law and codifying case law in EU legislation. The European Parliament, which had obtained a co-legislative role in EU decision-making, also called upon EU rules to limit legal uncertainty for patients. A first legislative attempt by the European Commission in 2004 to include healthcare in the Services Directive with severe restrictions on prior authorisation met with unbeatable opposition from national governments, the European Parliament and many interest groups. In response to the pressures of the internal market, the health ministers agreed on a set of common values and principles that emphasised the noneconomic tenets of the EU health systems, such as quality, safety, evidence-based ethical care, patient involvement, redress, privacy, and confidentiality (Council conclusions 2006). A second attempt by the European Commission followed in 2008 with the "directive on the application of patients' rights in cross-border healthcare" after extensive consultations with governments and interest groups. The European Parliament and the Council eventually agreed in 2011 on a substantially changed directive that enshrines the right to reimbursement for cross-border care 
provided by providers both within and outside of public health (insurance) systems under certain conditions. It requires member states to facilitate access to cross-border healthcare (with the exclusion of long-term care, organ transplantation and vaccination programs) by providing information to (future) patients on prior authorisation, reimbursement levels, quality and prices of healthcare and redress mechanisms, inter alia by National Contact Points. The directive also includes agreements on voluntary cooperation on issues such as reference networks, in particular for treating rare diseases, health technology assessment, and e-health.

In the protracted negotiations on the directive, prior authorisation regarding obtaining healthcare abroad was a fundamental issue in both the Council and the European Parliament. The final version of the directive states that authorisation can be applied not only for hospital care but also for highly specialised and cost-intensive care. Furthermore, member states define what 'highly specialised and cost-intensive care' is rather than the Commission, which it had originally proposed. Member states can also deny access to cross-border healthcare if there are concerns about the quality and safety of care of a specific health provider or if the care could pose a threat to a patient's safety or public health. Additionally, the directive explicates that member states can refuse to treat foreign patients for reasons of general interest under certain conditions. Thus, member states keep more territorial control over which type of healthcare could circulate freely than expected according to many interpretations of the CJEU case law and the Commission's proposal. The patients' rights directive also emphasises that member states are only obliged to reimburse up to what the same type of healthcare would cost back home. In this way, the financial impact of the directive is minimised and the possibilities for patients to use more expansive healthcare facilities elsewhere in the EU is limited. Member states also 
prevented the expansionary role the European Commission had foreseen for itself with respect to developing quality of care standards (Baeten and Palm 2012). In sum, despite the member states' incapacity to roll back CJEU case law entirely by means of primary law, they managed to insert more territorial control into secondary legislation than was originally indicated by the Commission and case law. This modification of the case law and a legislative text allowing more space for territorial politics facilitated the conclusion of a final compromise but ultimately confirmed an increasing EU role in healthcare. The trajectory of healthcare policies has thus not been simply a product of supranational steering by court and commission but has been shaped by national governments operating in specific institutional settings, in particular the jointdecision trap that is characteristic of cooperative federalism systems and territorial interests.

\section{Voluntary, sectoral cooperation by member states also in other arenas}

As indicated above, healthcare provided by parties other than the member states under the direct aegis of the EU is barely an option. However, even without an explicit treaty basis for legislating how to directly organise, finance, and provide healthcare, European healthcare integration could yet take root through voluntary sectoral policy cooperation (Obinger et al. 2005b: 567). As a relatively inexpensive means of increasing EU involvement, the European Commission provides the infrastructure for voluntary cooperation among member states and non-state actors such as health professionals and patient organisations. Through a variety of soft governance arrangements, such as informal committees, reflection processes, conferences, public consultations, health forums and joint actions, the discursive standardisation and further 
acceptance of EU involvement in healthcare can grow (Fierlbeck 2014). Meanwhile, studies that focus on healthcare systems are increasingly being funded by the EU Framework Programmes for Research (Legido Quigley et al. 2008). Through voluntary cooperation, the European Commission can thus set and keep healthcare policies on the European agenda. International comparison and mutual learning entail a certain measure of healthcare norm standardisation regarding issues such as quality of care and e-health applications for cross-border information exchange (Vollaard et al. 2013). Cooperation in other international organisations with overlapping membership is instrumental in this respect. For instance, the European Commission has made the healthcare quality indicators project of the Organisation of Economic Cooperation and Development (OECD) a matter of priority in its public health policies. Voluntary cooperation regarding safety and quality standards within the EU also relies on work of the Council of Europe (COE) and the World Health Organisation-Europe (WHO).

EU legislative initiatives in healthcare may yet encounter intractable resistance from national governments in formal arenas such as the Council, but cooperation among policy experts in the health sector could overcome the joint-decision trap (Peters 1997). In the end, member states are not unitary actors. Moreover, member states might not want EU healthcare policy covered by hard law, but they might see advantages in participating in soft governance arrangements. For example, since the 1990s, EU ministers who are responsible for social protection have exchanged ideas about how to counteract pressures from the internal market and to meet the social policy objectives in the non-binding arrangements that were later called the Open Method of Coordination (Fierlbeck [2014]; Greer and Vanhercke [2010]; Princen [2009]). Furthermore, informal meetings allowed national high-level civil servants to discuss the 
sensitive issue of cross-border healthcare and related issues in response to the CJEU verdicts (Hervey and Vanhercke 2010). Meanwhile, ministers not only of social and health affairs but also of finance and economic affairs sought opportunities to learn how to maintain the financial sustainability of healthcare systems in the face of changes such as demanding citizens, an ageing population, and technological advancements. These changes raise questions such as how to keep high-quality care accessible for everyone, how to enhance social inclusion through health-improving policies, and how to foster the growth potential of the medical sector (Greer and Vanhercke 2010). Although national governments have continued to emphasise their responsibilities regarding organising and financing their healthcare systems, the various directorates-general of the European Commission could thus offer platforms to diffuse policy ideas, which could limit the diversity of healthcare systems. This also prepares-in combination with the standardisation of healthcare norms from arenas within and outside of the EU-the ground for more binding EU interference.

First, elaborating on 'soft' charters, declarations, conventions and recommendations by the EU, the COE and WHO, the Lisbon Treaty enshrines patients' rights with a reference to the binding Charter of Fundamental Rights of the EU, stating that "everyone has the right of access to preventive health care and the right to benefit from medical treatment under the conditions established by national laws and practices". In addition, informal platforms for discussing the impact of CJEU case law on healthcare systems eventually generated acceptance among the member states and other healthcare actors in order to limit legal uncertainty by adopting a directive on how to apply patients' rights in cross-border healthcare. 


\section{Member states' fiscal stress}

Comparative federalism literature suggests fiscal stress at the member state level as a factor that allows for increasing influence of the central authorities (Obinger et al. 2005a: 45). Financial dependence offers the opportunity for central authorities to provide financial support in exchange for a say in certain policy matters. For example, in Canada, labour mobility and demographic differences between the provinces resulted in fiscal imbalances in the provinces' social security systems beginning in the 1930 s (Banting 1995, 2005). Leaving the classic model of dual federalism behind, the Canadian provincial and federal authorities subsequently shifted towards shared-cost federalism, albeit less so since the late 1990s. The EU has also become more closely involved with national healthcare systems when countries face fiscal stress. Candidate member states have received financial support and recommendations to undo their social-economic weaknesses by strengthening their health infrastructures. EU structural funds include financial support for healthcare-related issues in economically weak regions, even though the organisation of healthcare systems itself was excluded until recently (Hervey and Vanhercke 2010: 91). Guidelines with respect to healthcare to coordinate public budgets within the framework of the Stability and Growth Pact encompassed within the Economic and Monetary Union were rather general and non-binding (Baeten and Thomson 2012). The debt crises resulted in a major change in this respect. The adjustment programmes for debt-struck countries, such as Greece, Portugal and Cyprus, included specific prescriptions for controlling their healthcare budgets in exchange for financial assistance, following policy solutions that had 
been discussed in voluntary schemes before (Baeten and Thomson [2012]; Fahy [2012]; Fierlbeck, [2014]; Greer [2014]). In a European semester, combining a reinforced Stability and Growth Pact and closer economic policy coordination to meet the targets of the Europe 2020 growth strategy, the EU has obtained a more stringent role in supervising national budgets and the economic growth potential of the Eurozone member states. The European semester, beginning with the Annual Growth Survey of European Commission-which outlined the economic priorities-also includes increasingly detailed recommendations on financing and organising healthcare. If Eurozone members fail to contain their budget deficits and public debts, warnings and sanctions may follow (Baeten and Thomson 2012). The predominant economic and financial nature of the European Semester provoked health and social actors within member states and the European Commission to address healthcare more specifically (see, e.g., European Commission 2013). This growing EU involvement with national healthcare systems has already been qualified as a "competence grab" and "the biggest power shift since the single market was set up" (Keating 2013). Even without a large budget or a self-contained tax base, the EU could more easily interfere in healthcare policies because of the increasingly dependent role of member states in times of fiscal stress.

\section{THE NATURE OF THE EUROPEAN HEALTHCARE UNION IN THE MAKING}

Even though healthcare can be considered a least likely case of European integration (Martinsen 2005), the EU has increasingly become involved in the matter. A European healthcare union is in the making. Healthcare is now produced, consumed and provided across 
the internal borders of the EU (common use), multiple common values and standards have been agreed upon, common institutions that are directly related to health have been established, and common regulations (Coordination Regulations; patients' rights directive) based on the specific subset of EU health laws (Hervey and McHale 2015) and some manner of common financing (in countries with fiscal stress) now occur. Certainly, national healthcare systems have not been fully integrated into a single European healthcare system, but the EU has become an extra, albeit thin, layer in organising, financing and providing healthcare. Although a European healthcare union initially seemed unlikely from a federalist perspective, this same perspective helped us to understand how it could have eventually emerged nevertheless. The specific institutional settings in the EU, such as the interpretative role of the CJEU, the Commission's right of initiative, and the joint-decision trap, have shaped the trajectory of the European healthcare union. Although the member states have not been able to fully roll back the EU's influence, the cooperative federal dynamic has allowed territorial politics to be voiced in decision-making, making it possible to modify the impact of CJEU case law and allow for more territorial control of patient flows than was originally envisioned by the European Commission. Instead of exclusively focusing on national governments and their preferences or on supranational actors and spill-over effects, federalist theory has thus shown its explanatory value in enabling a more comprehensive analysis of the dynamics of allocating healthcare tasks, in which both national governments and supranational actors can and do play an active role within the specific institutional settings of the EU. The European healthcare union is a combination of regulatory and voluntary arrangements. Starting from a condition of dual federalism, it has become a cooperative federative system that combines self-rule (a large part 
of healthcare is still organised by member states) and shared rule (mainly concerning the collective coordination of cross-border healthcare and the market of health goods, services, persons and capital). It is important to note that the mechanisms may be comparable with those of other federal systems, but their actual contents are not. For example, the EU does not run programmes to pay health professionals for their services or provide patients with subsidised prescribed drugs, as in Australia, and it does not provide federal grants to member states' healthcare systems to the extent Canada and the USA do. Its limited financial means deny the EU the opportunity to equalise differences in quality of and access to healthcare within the EU. It thus remains an instance of cooperative federalism in the foreseeable future.

The imperative question, however, is whether this combination of self-rule and shared rule will hold. The robustness of federal systems depends on 1) structural, electoral and judicial safeguards that guarantee the division of rule and 2) the 'glue' provided by political parties operating across various levels of government and a popular federal culture (Bednar 2009). The division of rule in the area of healthcare is enshrined in the treaties, which can only be modified by elected parliaments. This structural division is, however, not safe from CJEU case law, which raised considerable protest from member states in the past. Nevertheless, the opportunity for states' governments to voice their protests within the EU could have prevented them from opting for a (partial) exit from the EU instead. The European healthcare union is still frail in terms of its party-political and popular safeguards; most political parties prefer to keep EU involvement in healthcare at bay. In other multilevel polities, healthcare policies have been an important instrument for fostering a common culture and strengthening political legitimacy. For example, in the case of Canada, financial transfers from federal authorities to states have 
enhanced the sense of belonging within the federal community and the legitimacy of the federal authorities (Banting 1995, 2005). It is thus no surprise that the province of Quebec has initiated welfare arrangements to strengthen the provincial community instead. The EU has also perceived initiatives for cross-border healthcare as a means of giving EU citizenship more substance. For instance, the decision to introduce the European Health Insurance Card was celebrated by the European Parliament and the European Commission as an important step for European citizenship; the then president of the European Commission, Romano Prodi, proudly presented the card as an important contribution to European identity (Vollaard 2006). Furthermore, after the CJEU underlined citizens' rights to obtain healthcare abroad and to be reimbursed for said care, the European Commission gradually began to describe patient mobility in its communications and documents no longer as a side effect of the internal market but as a right of European citizens. Additionally, after the French and Dutch voted no against the European Constitutional Treaty in the spring of 2005, the European Commission justified a renewed initiative regarding health services in 2007 on the basis of its "Citizens' Agenda" to enhance the legitimacy of the European Union. Healthcare is thus used as an instrument to foster a European sense of belonging among the citizens of the EU member states-the question, however, is to what effect.

In the EU, the initial division of rule caused market-making policies to precede marketcorrected and health-oriented policies. This sequence of developments has left its mark on the EU's healthcare policies. Growing EU involvement has often been a by-product of expanding the free movement of goods, services, and labour in the internal market and has therefore been rather a commodifying power, even if the CJEU has increasingly taken into account 
governments' concerns about the financial viability and solidarity of healthcare systems (Hatzopolous and Hervey 2013). Commodification means individualising choice options, in contrast with a system of collective solidarity in which poor and rich, sick and fit, old and young share health risks. Moreover, a greater supply of healthcare outside of the national territory can be more easily obtained by younger, higher educated, high income citizens who seek elective care than by older, chronic patients with limited means and language capacities. Individualisation is also emphasised by the focus on the rights of individual patients in the recent patients' rights directive. This individualised nature of the European healthcare union does not foster 'we-ness', a mutual sense of belonging together, and the limited we-ness is recently reflected in the calls in England and Germany to limit access to healthcare for workers from Bulgaria and Romania. The caps on healthcare funding that were demanded in the economic adjustment programmes for countries such as Greece and Portugal or healthcare reforms that were recommended in the European semester will not generate warm feelings towards the EU either, particularly when national governments use the EU itself as a scapegoat. In sum, the European healthcare union does not appear in practice to be instrumental in strengthening the EU's legitimacy and mutual sense of belonging. With such a weak popular safeguard, the European healthcare union is still not robust.

Biographical notes Hans Vollaard is lecturer in Dutch and European Politics at the Political Science Department of Leiden University, the Netherlands. Hester van de Bovenkamp is assistant professor of Public Administration at the institute of Health Policy \& Management of 
the Erasmus University Rotterdam, the Netherlands. Dorte Sindbjerg Martinsen is professor (MSO) at the Department of Political Science, University of Copenhagen

Addresses for correspondence Hans Vollaard, Department of Political Science Leiden University, Wassenaarseweg 52, 2333 AK Leiden, The Netherlands. Email: vollaard@fsw.leidenuniv.nl / Hester van de Bovenkamp, institute of Health Policy \& $\begin{array}{lllll}\text { Management, Erasmus University } & \text { Rotterdam, } & \text { P.O. } & \text { Box } & 1738\end{array}$ 3000 DR Rotterdam, The Netherlands. Email: vandebovenkamp@bmg.eur.nl / Dorte Sindbjerg Martinsen, Department of Political Science, University of Copenhagen, Øster Farimagsgade 5, 1353 København K, Denmark. Email: $\underline{\text { dm@ifs.ku.dk }}$

\section{ACKNOWLEDGEMENTS}

Financial support from the Danish Research Council project no. 10-079675/FSE is gratefully acknowledged. We would like to thank Thomas Kostera, Scott Greer, Paul Robben, Tamara Hervey, the three anonymous referees and the participants of the panel "Welfare Federalism in the Making? Welfare Policies, Member States and the EU" at the ECPR General Conference in Bordeaux (2013), of the Governance session of the Institute of Health Policy \& Management of the Erasmus University Rotterdam (2013) and of the workshop “Cross-border Healthcare Law in the European Union: Current Status and Implications"(2014) in Copenhagen for their valuable comments on previous versions of this paper. 


\section{REFERENCES}

Baeten, R. and Thomson, S. (2012) 'Healthcare policies: European debates and national reforms', in Social Developments in the European Union 2011, Brussels: ETUI/OSE, pp.87-212.

Banting, K. (1995) 'The welfare state as statecraft: territorial politics and Canadian social policy', in S. Leibfried and P. Pierson (eds), European Social Policy: between Fragmentation and Integration. Washington, DC: Brookings Institution Press, pp.269-300.

Banting, K. (2005) 'Canada: Nation-building in a federal welfare state', in H. Obinger, S. Leibfried and F. Castles (eds), Federalism and the Welfare State: New World and European Experiences, Cambridge: Cambridge University Press, pp.89-137.

Bednar, J. (2009) The Robust Federation: Principles of Design, Cambridge: Cambridge University Press.

Benson, D. and Jordan, A. (2008) 'Understanding task allocation in the European Union: Exploring the value of federal theory', Journal of European Public Policy 15(1): 78-97.

Benson, D. and Jordan, A. (2011) 'Exploring the Tool-kit of European Integration Theory: What Role for Cooperative Federalism?' Journal of European Integration 33(1): 1-17.

Börzel, T. and Hosli, M. (2003) 'Brussels between Bern and Berlin: Comparative federalism meets the European Union', Governance: An International Journal of Public, Administration, and Institutions 16 (2): 179-202. 
Egeberg, M. (2001) 'How federal? The organizational dimension of integration in the EU (and elsewhere)', Journal of European Public Policy 8(5): 728-746.

Elazar, D. (1987) Exploring Federalism, Alabama: University of Alabama Press.

European Commission (2010), 'Eurobarometer 74', Brussels, autumn, available at http://ec.europa.eu/public_opinion/archives/eb/eb74/eb74_en.htm (accessed September 2014).

European Commission (2013) 'Investing in Health', SWD(2013) 43 final, 20 February, Brussels, available at http://ec.europa.eu/health/strategy/docs/swd_investing_in_health.pdf (accessed September 2014).

Fahy, N. (2012) 'Who is shaping the future of European health systems', British Medical Journal $344: 31712,1-5$

Fierlbeck, K. (2014) 'The changing contours of experimental governance in European health care', Social Science \& Medicine 108: 89-96.

Glinos I., Doering N., and Maarse, H. (2012) 'Travelling home for treatment and EU patients' rights to care abroad: results of a survey among German students at Maastricht University', Health Policy 105: 38-45

Greer, S. (2006) 'Uninvited Europeanization: Neofunctionalism and the EU in health policy', Journal of European Public Policy 13(1): 134-152. 
Greer, S. (2009) The Politics of European Union Health Policies, Berkshire: Open University Press.

Greer, S. (2011) 'The weakness of strong policies and the strength of weak policies: Law, experimentalist Governance, and supporting coalitions in European Union health care policy', Regulation \& Governance 5: 187-203.

Greer, S. (2014) 'The three faces of European Union health policy: Policy, markets, and austerity', Policy and Society 33(1): 13-24.

Greer, S. and Rauscher, S. (2011) 'Destabilization rights and restabilization politics: Policy and political reactions to European Union healthcare services law', Journal of European Public Policy, 18:2 220-240.

Greer, S. and Vanhercke, B. (2010) 'The hard politics of soft law: The case of health', in E. Mossialos et al. (eds), Health Systems Governance in Europe: The Role of European Union Law and Policy, Cambridge: Cambridge University Press, pp.186-230.

Hatzopoulos, V. and Hervey, T. (2013) 'Coming into line: The EU's court softens on cross-border health care', Health Economics, Policy and Law 8(1): 1-5.

Hervey, T. and Vanhercke B. (2010) Healthcare and the EU: The law and policy patchwork', in E. Mossialos et al. (eds), Health Systems Governance in Europe: The Role of European Union Law and Policy, Cambridge: Cambridge University Press, pp.84-133.

Hervey, T. and McHale, J. (2015) European Union Health Law: Themes and Implications, Cambridge: Cambridge University Press. 
Keating, D. (2013) 'The EU's healthy intervention', European Voice 11 April.

Kelemen, R. (2003) 'The structure and dynamics of EU federalism', Comparative Political Studies 36(1/2): 184-208.

Lamping, W. (2005) 'European integration and health policy: A peculiar relationship', in M. Steffen (ed.), Health Governance in Europe: Issues, Challenges and Theories, London: Routledge, pp.18-48.

Lamping W. and Steffen M. (2009) 'European Union and Health Policy: The "Chaordic" Dynamics of Integration', Social Science Quarterly 90:1361-79

Legido-Quigley H., McKee M., Nolte E., Glinos I. (2008) 'Assuring the quality of health care in the European Union: a case for action', Copenhagen: WHO.

Martinsen, D. (2005) 'Towards an internal health market with the European Court', West European Politics 28(5): 1035-1056.

Martinsen, D. and Falkner, G. (2011) 'Social policy: problem-solving gaps, partial exits, and court-decision traps', in G. Falkner (ed.), The EU's Decision Traps: Comparing Policies, Oxford: Oxford University Press, pp.128-144.

McKee, M., Hervey, T. and Gilmore, A. (2010) 'Public health policies', in E. Mossialos et al. (eds), Health Systems Governance in Europe: The Role of European Union Law and Policy, Cambridge: Cambridge University Press, pp.231-280. 
Mossialos, E., Permanand, G., Baeten, R. and Hervey, T. (eds) (2010) Health Systems Governance in Europe: The Role of European Union Law and Policy, Cambridge: Cambridge University Press.

Notes of the Trio Presidency (2007) 'Healthcare across Europe: Striving for Added Value', 20 April, Aachen, available at http://www.eu2007.de/en/News/download_docs/April/0419BSGV/090Triopapier.pdf (accessed September 2014).

Obinger, H., Castles, F. and Leibfried, S. (2005a) 'Introduction: Federalism and the welfare state', in H. Obinger, S. Leibfried and F.G. Castles (eds), Federalism and the Welfare State: New World and European Experiences, Cambridge: Cambridge University Press, pp.1-48.

Obinger, H., Leibfried, S. and Castles, F. (2005b) 'Bypasses to a social Europe? Lessons from federal experience', Journal of European Public Policy 12(3): 545-571.

Palm, W. and Baeten, R. (2011), 'The Quality and Safety Paradox in the Patients' Rights Directive', European Journal of Public Health 21:3, 272-274.

Parsons, C. (2003) A Certain Idea of Europe, New York: Cornell University Press.

Peters, B. (1997) 'Escaping the joint-decision trap: Repetition and sectoral politics in the European Union, West European Politics 20:2, 22-36.

Princen, S. (2009) Agenda-setting in the European Union, Basingstoke: PalgraveMacMillan.

Risse, Th. (2005) 'Nationalism, European identity, and the puzzles of European integration', Journal of European Public Policy 12(2): 291-309. 
Scharpf, F. (1988) 'The joint-decision trap: Lessons from German federalism and European integration', Public Administration 66(3): 239-278.

Scharpf, F. (2011) 'The JDT Model: Context and Extensions', in G. Falkner (ed.), The EU's Decision Traps: Comparing Policies, Oxford: Oxford University Press, pp.217-237.

Streeck, W. (1995) 'From market making to state building? Reflections on the political economy of European social policy', in S. Leibfried and P. Pierson (eds), European Social Policy: Between Fragmentation and Integration, Washington (DC): The Brookings Institution, pp.389-431.

Thomson, S. and Mossialos, E. (2010) 'Private health insurance and the internal market', in in E. Mossialos et al. (eds), Health Systems Governance in Europe: The Role of European Union Law and Policy, Cambridge: Cambridge University Press, pp.419-460.

Trubek, L., Nance, M. and Hervey, T. (2009) 'The construction of healthier Europe: Lessons from the fight against cancer', Wisconsin International Law Journal 26(3): 804-843.

Vollaard, H. (2006) 'European integration and unfreezing territoriality: The case of the European health card', in R. Holzacker and M. Haverland (eds), European Research Reloaded, Dordrecht: Springer, pp.203-228.

Vollaard, H., Van de Bovenkamp, H. and Vrangbæk, K. (2013) 'The emerging EU quality of care policy: From sharing information to enforcement', Health Policy 111: 226-233. 